\title{
THE DISTRIBUTION AND SOME ECOLOGICAL ASPECTS OF MARINE ALGAL GENUS EUCHEUMA IN THE INDONESIAN WATERS
}

\author{
by \\ WANDA SURJANA ATMADJA ${ }^{1)}$ and SULISTIJO ${ }^{1)}$
}

\begin{abstract}
Eight species of Eucheuma ait found to grow in the Indonesian waters making the amount of species of Eucheuma which had been found become 17 species. A certain species specifically found only in certain areas. Those species are usually found at the depths of 30 to $150 \mathrm{~cm}$ during low tide at the reef flat, moat and algal ridge of the coral reefs where temperatures and salinities varied from $29^{\circ}$ to $31^{\circ}$ and from 30 to $34 \%$ respectivelly. There are various habitats of Eucheuma i.e. dead and live corals, limestones, sand and shells.

Average wet weight biomass of Eucheuma species at the areas investigated varied from 2 to $552 \mathrm{~g} / \mathrm{m}$. The highest value is that of Eucheuma spinosum found in East Seram (Maluku), and the lowest is that of E. cottonii found in the Keifing Island, East Seram. The species of Eucheuma commonly found in association with Acanthopora, Gracilaria and Halimeda.
\end{abstract}

\begin{abstract}
ABSTRAK
Jumlah jenis Eucheuma yang telah didapati dari perairan Indonesia menjadi 17 jenis, setelah hasil penelitian yang dilakukan oleh penulis mendapat 8 jenis. Jenis-jenis tersebut tumbuh pada kedalaman 30-150 cm di rataan terumbu karang dengan suhu antara 29-31 ${ }^{\circ} \mathrm{C}$ dan salinitas berkisar antara 30 $34 \% \wedge$. Ada beberapa habitat tempat tumbuh Eucheuma antara lain karang mati, batuan, kulit kerang pasir dan karang hidup.

Berat rata-rata biomassa Eucheuma di lokasi penelitian bervariasi dari 2-552 g/m². Nilai terbesar adalah jenis Eucheuma spinosum di Seram Timur (Maluku) dan terendah adalah Eucheuma cottonii di Pulau Keifing (Maluku). Jenis-jenis Eucheuma biasanya tumbuh bersama-sama dengan jenis lainnya, yaitu Acanthopora, Gracilaria dan Halimeda.
\end{abstract}

\section{INTRODUCTION}

The Indonesian Archipelagois located between $94^{\circ}-141^{\circ} \mathrm{E}$ and $6^{\circ}-11^{\circ} \mathrm{S}$, consisted of 13,667 islands with more than $81,000 \mathrm{~km}$ of coast line. The Indonesian waters cover two-thirds of the Indonesian territory. Those conditions make the Indonesian waters have a big potential of seaweeds. Therefore the investigation and research on the marine algas in Indonesia are very important.

There are many species of seaweeds grow in the Indonesian waters. From the results of the Siboga Expedition (1899-1900), which focused its attention on the marine flore and fauna and its biogeography, Bosse (1928) found 14 species of

1) Centre for Oceanological Research and Development, P.O. Box 580 DAK, JAKARTA. 
red algae of the genus Eucheuma in Indonesian waters composed of Eucheuma leeuwenii, E. serra. E. muricatum, E, crustaeforme, E. horizontale, E. adhaerens, E. edule, E. crassum, E. vermiculare, E. dishotomum, E. cervicorne, E. arnoldii, E. striatum and E. simplex. The red algal genus Eucheuma in Indonesian is economically important as carrageenan source, almost all of it production is exported. The seaweeds export from Indonesia mostly of Eucheuma spinosum. Most of their production is harvested from the natural stocks. However, the experimental cultivations of some species especially E. spinosum have been carried out and developed continuously at some areas in the Indonesian water (SAHUPALA et al 1977, Mubarak 1978 and Soegiarto etal 1978).

Investigations to reveal aspects of growth and ecology in natural communities will be very important. The present authors are interested in these problems and through this paper attempt to reveal the distribution and some ecological aspects of Eucheuma in Indonesian waters.

\section{MATERIAL AND METHODS}

The investigations are carried out at some areas in the Indonesian waters : West Jawa, Sunda Strait, Seribu Islands, Bali, Southeast and Central Sulawesi, and Maluku. The kind of substrates, depth, water temperature and salinity are observed on each area investigated.

Transect methods are used in these investigations. Collecting material is done from those areas within one square metre of each ten metres interval along the transect line at the reef flats. Samples collected from each area are weighed for wet biomass. ,

\section{RESULTS}

\section{Distribution}

The algal genus Eucheuma is found to grow at some areas investigated in the Indonesian waters (Table 1 and Figure 1). The authors find eight species of Eucheuma: E. spinosum (E. muricatum). E. edule, E. serra, E. cottonii, E. crassum, E. arnoldii, Eucheuma sp. 1 and Eucheuma sp. 2. They usually grow on the coral reef flats, commonly in the intertidal zones i.e. on the moats and algal ridges. E. spinosum can be found in almost all of the area investigated. Another investigations of Eucheuma in the Indonesian waters had been carried out by Bosse (1928), Suryodinoto (1970) and Mubarak (1974) were also described in Table 1 and Figure 1.

\section{Some ecological aspects}

Eucheuma mostly grows at the reef flat areas of the fringing coral reefs. There are three types of profiles of the coral reefs (Fig. 2). Accordingly Eucheuma grows in 


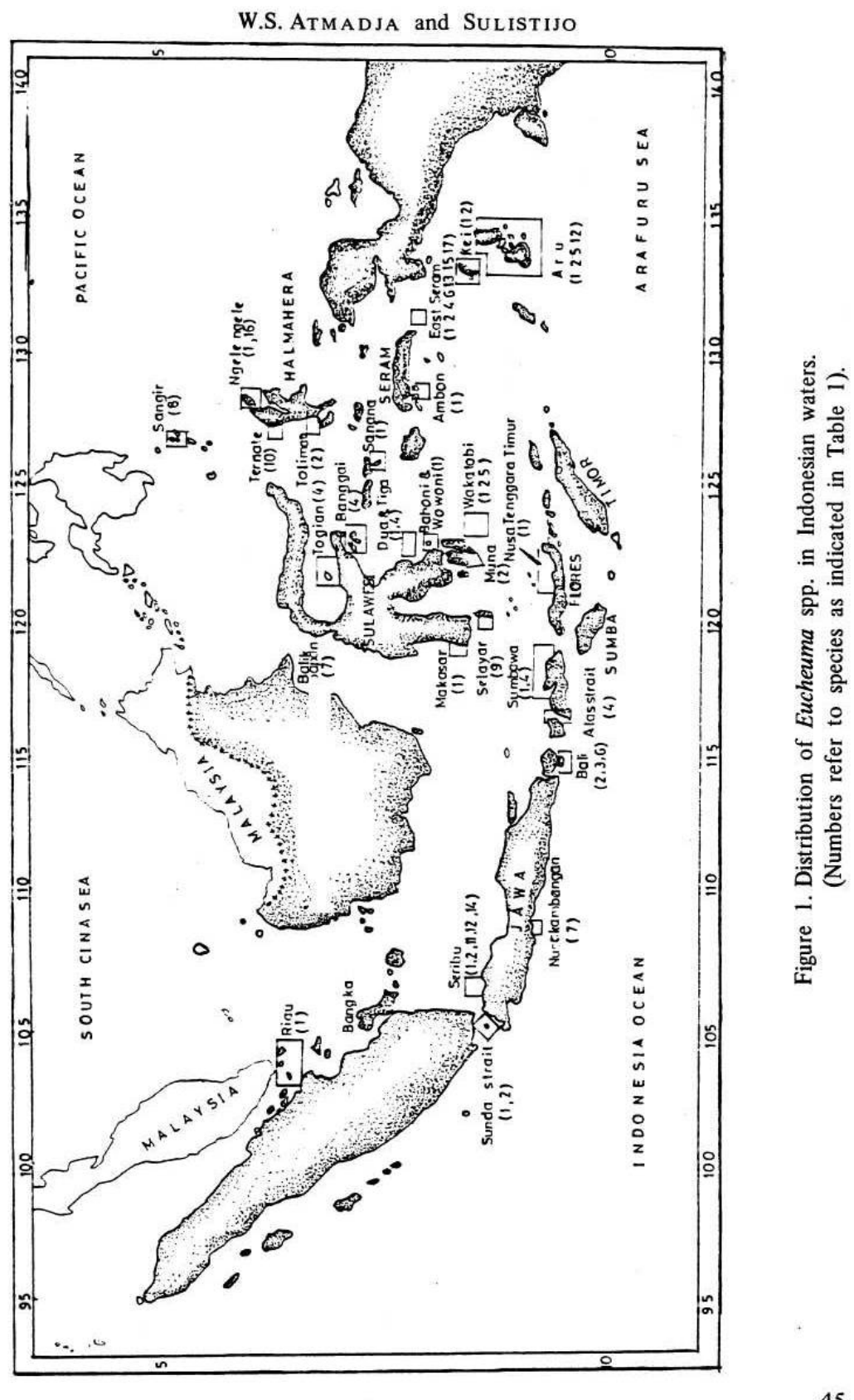


Marine Algal of the Genus Eucheuma

Table 1. Distribution of Eucheuma spp. in the Indonesia waters.

\begin{tabular}{|c|c|c|c|}
\hline No. & Species & Locations & Source \\
\hline 1. & Eucheuma & $\begin{array}{l}\text { Seribu Isls., Sunda strait (Cilurah, } \\
\text { Sebesi Isl.). Southeast Sulawesi } \\
\text { (Wakatobi and Muna Isl.). Central } \\
\text { Sulawesi (Banggai and Togian Isl.), } \\
\text { Maluku (Ngele-ngele, Sanana, East } \\
\text { Seram Kei and Aru Isl.), Jawa, } \\
\text { Seribu Isl, Sumbawa, Makasar, Kei, } \\
\text { Aru, Balikpapan, Riau and Ambon. } \\
\text { Sumbawa, Central Sulawesi (Dua, } \\
\text { Tiga, Bakori and Wawoni Isl.), } \\
\text { Nusa Tenggara Timur and Maluku. } \\
\text { Riau Islands. }\end{array}$ & $\begin{array}{l}\text { Van Bosse } \\
\text { (1928) } \\
\text { Soeryodinoto } \\
(1970) \\
\text { Mubarak (1974) } \\
\text { UNRI (1975) }\end{array}$ \\
\hline 2. & E. edule & $\begin{array}{l}\text { Seribu Isls., Bali (Senos and Jim- } \\
\text { baran), Southeast Sulawesi (Waka- } \\
\text { tobi and Muna Isl.), Maluku (Toli-- } \\
\text { mao, East Seram, Kei and Aru Isl.). } \\
\text { Seribu Isls. and Kei Isls. } \\
\text { Central Sulawesi (Dua and Tiga } \\
\text { Islands). }\end{array}$ & $\begin{array}{l}\text { Van Bosse (1928) } \\
\text { Soeryodinoto } \\
\text { (1970) }\end{array}$ \\
\hline 3. & Eucheuma serra & $\begin{array}{l}\text { Bali (Benoa and Jimbaran) } \\
\text { Bali }\end{array}$ & $\begin{array}{l}\text { The authors } \\
\text { Van Bosse (1928) }\end{array}$ \\
\hline 4. & E. cottonii & $\begin{array}{l}\text { Central Sulawesi (Banggai and } \\
\text { Togian Isl.). Maluku (East Seram). } \\
\text { Alas Strait and Sumbawa, Central } \\
\text { Sulawesi (Tiga Isl.). }\end{array}$ & $\begin{array}{l}\text { The authors } \\
\text { Soeryodinoto } \\
\text { (1970) }\end{array}$ \\
\hline 5. & E. crassum & $\begin{array}{l}\text { Southeast Sulawesi (Wakatobi Isl.). } \\
\text { Maluku (Aru) }\end{array}$ & $\begin{array}{l}\text { The authors } \\
\text { Van Bosse (1928) }\end{array}$ \\
\hline 6. & E. arnoldii & $\begin{array}{l}\text { Bali (Benoa) } \\
\text { Maluku (Ceser/East Seram). }\end{array}$ & $\begin{array}{l}\text { The authors } \\
\text { Van Bosse (1928) }\end{array}$ \\
\hline 7. & E. leeuwenii & Jawa (Nusa Kambangan) & Van Bosse (1928) \\
\hline 8. & E. crustaeforme & North Sulawesi (Sangir Isl.). & Van Bosse (1928) \\
\hline 9. & E. horizontale & South Sulawesi (Selayar Isl.). & Van Bosse (1928) \\
\hline 10. & E. adhaerens & Maluku (Ternate Isl.). & Van Bosse (1928) \\
\hline 11. & E. vermiculare & Seribu Islands. & Van Bosse (1928) \\
\hline
\end{tabular}


W.S. Atmadja and Sulistijo

Tabel 1. (Continued)

\begin{tabular}{r|l|l|l}
\hline No. & \multicolumn{1}{|c|}{ Species } & \multicolumn{1}{|c}{ Locations } & \multicolumn{1}{|c}{ Source } \\
\hline 12. & E. dichotomum & Seribu Isls., Maluku (Kei and Elat) & Van Bosse (1928) \\
13. & E. cervicorne & Maluku (Geser/East Seram) & Van Bosse (1928) \\
14. & E. striatum & Seribu Islands & Van Bosse (1928) \\
15. & Eucheuma simplex & Maluku (Geser/East Seram). & Van Bosse (1928) \\
16. & Eucheuma sp. 1. & Maluku (Ngele-ngele kecil). & The authors \\
17. & Eucheuma sp. 2. & Maluku (East Seram) & The authors \\
& & & \\
\hline
\end{tabular}


all those at depths of $30-150 \mathrm{~cm}$ during the means low tide. The water is usually clear, so that the plants can be seen from water surface. Water temperature varies from 29 to $31^{\circ} \mathrm{C}$. Salinity usually between $30-34 \%$. The lower salinity usually found in the western part of the Indonesian waters and the higher salinity in the eastern part. Eucheuma spinosum and E. cottonii usually grow on dead coral fragments, $E$. spinosum also grows on shells, limestones (found at Geser Island in Maluku). Eucheuma serra is found only at the algal ridges on dead corals (found at Tanjung Benoa and Jimberan, Bali) and usually grows weel at the areas which subjected to the direct surf. Eucheuma edule is usually found on dead corals and sandy habitats. All of those algas can also be found to grow at the exposed reef areas.

Average wet weight (biomass) per square metre of Eucheuma spinosum, E. edule, E. cottonii and E. serra varies from 11 to $552 \mathrm{~g}, 16$ to $114 \mathrm{~g}$, and 49 to $52 \mathrm{~g}$ respectively (Table 2). The messurements indicate that the seaweed form mixed population which make the density of Eucheuma low.

The other algal genera, such as Acanthopora, Gracilaria, and Halimeda were always found at the Eucheuma community in almost all of the locations investigated.

\section{DISCUSSION}

Most of the locations investigated in the Indonesian waters have no Eucheuma at all. This algal genus was found only in certain locations. Which is not surprising because Eucheuma requires special ecological conditions.

Eucheuma arnoldii displays- a unique characteristic, it was never found in the surf zone. In these investigations, E. arnoldii was found only at Tanjung Benoa, Bali and VAN-Bosse (1928) found at Gaser, Maluku. light and desiccation seem to be the major ecological factors influencing $E$. spinosum which grows in the sheltered waters of inner reefs. Eucheuma cottonii shows the greatest tolerance to depth, desiccation, current strength and substrate types (DOTY 1970). SOERYODINOTO (1970) reported $E$. spinosum and E, cottonii from the other areas in the Indonesian waters i.e. Sumbawa, Alas Strait, Dua and Tiga Island. He also stated that E. spinosum was found in the Madilan Island at the clear water area and from turbid area in the coast of Lambu Bay. E.spinosum was also found in Riau (UNRI 1975). The important potential areas of $E$. spinosum in the Indonesian waters are Central and Southeast Sulawesi, Maluku, Nusa Tenggara Timur and Nusa Tenggara Barat (SoEgiarto et al.1970). There is still no information yet about the occurrence of E. serra at the other areas in the Indonesian waters except Tanjung Benoa and Jembaran, Bali. This algae has been reported from Ryu Kyu Formosa Japan (Levring et al 1969) and Luzon (Cordero 1977). Apparently, E, serra requires more specialized habitats than other Eucheuma species.

Almost all of the eight Eucheuma species found by the authors in the Indonesian waters were also found by CORDERO (1977) in the Philippines waters. One of the species, E. cottonii,w2iS not reported by VAN-BOSSE (1928) during the 

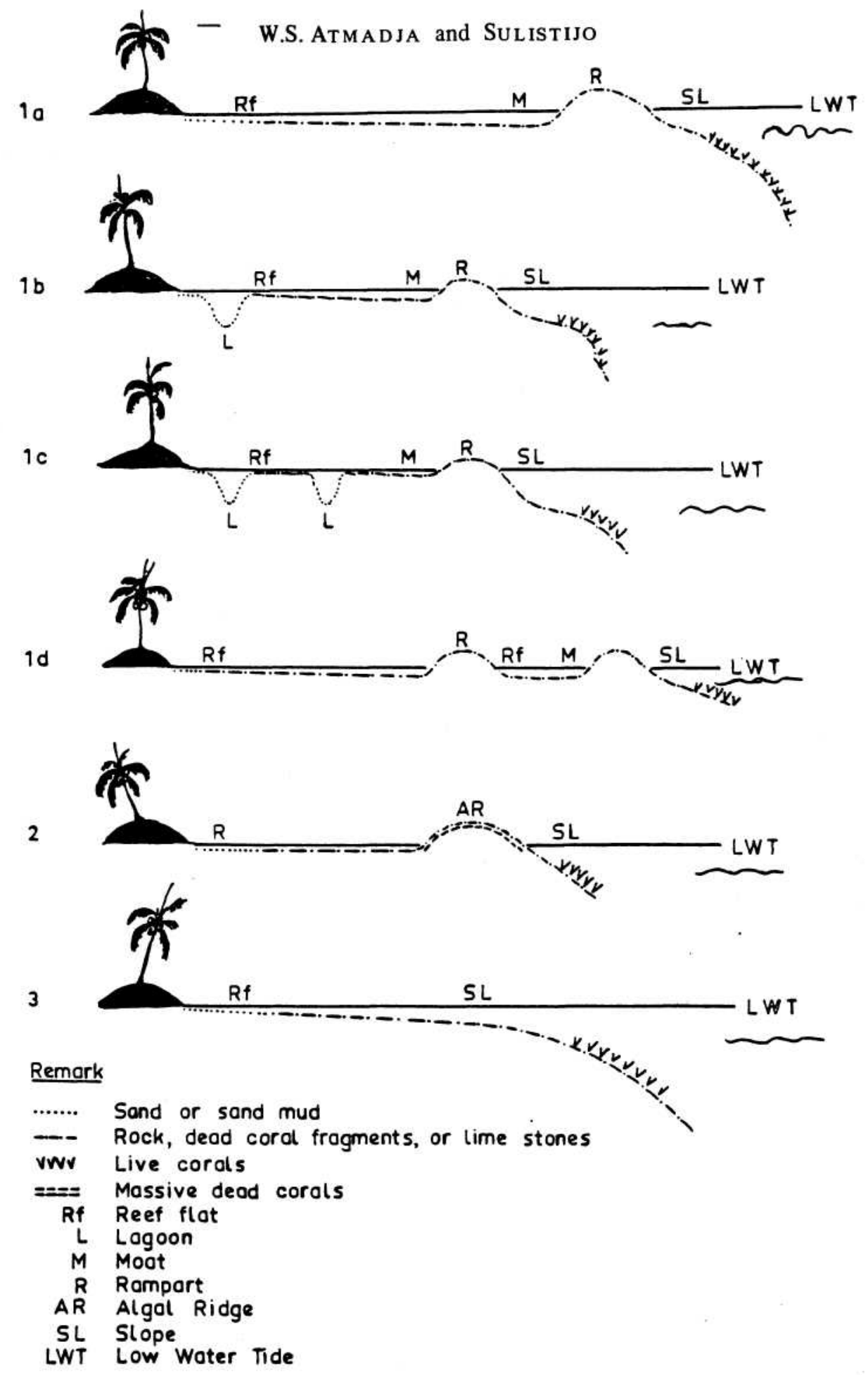

Figure 2. Three profil types of the Coral Reef areas as algal habitats 
Marine Algal of the Genus Eucheuma

Tabel 2. Biomass of algal genus Eucheuma at some locations in the Indonesian waters.

\begin{tabular}{l|l|c}
\hline \multicolumn{1}{c|}{ A $1 \mathrm{~g}$ a e } & \multicolumn{1}{|c}{ Locations } & $\begin{array}{c}\text { Average } \\
\text { biomass }\left(\mathrm{g} / \mathrm{m}^{2}\right)\end{array}$ \\
\hline \multirow{3}{*}{ Eucheuma spinosum } & East Seram & 552 \\
& Ngele-ngele kecil Isl. & 48 \\
& Cilurah & 40 \\
& Kobror Isl./Aru & 176 \\
& Tayandu Islands/Aru & 377 \\
E. edule & Seribu Islands Group & 11 \\
& Keifing Island/East Seram & 114 \\
E. cottonii & Seribu Islands Group & 16 \\
E. serra & East Seram & 2 \\
& Tanjung Benoa (Bali) & 49 \\
Eucheuma sp. 2. & Jimbaran (Bali) & 52 \\
& East Seram & 108 \\
& & \\
\hline
\end{tabular}




\section{W.S. Atmadja and Sulistijo}

Siboga Expedition in the Indonesian waters. The other seven species of Eucheuma found by the authors were also reported by VAN-BossE (1928), during the Siboga Expedition, even make their distribution become wider in the Indonesian waters. Four species of them i.e. E. spinosum, E. Edule, E. cottonii and E. serra are of utmost commercial importance. The highest export volume is composed of E. spinosum which is harvested from the natural stocks, mostly from Maluku waters. Eucheuma spinosum harvested from farming is only from Tanjung Benoa, Bali (Soegiarto and Sulistijo 1981) and Samaringa, Sulawesi (Ismail 1982). The highest average value of the biomas (in wet weight) of $E$. spinosum per square metre is $552 \mathrm{~g}$ in East Seram, whereas the lowest biomass was measured for $E$. cottonii from Keifing Island, East Seram (Table 2.). They were obtained from the standing crop measurement along the transect lines. Biomass of E. spinosum at the selected site in East Seram reached a density of $8,000 \mathrm{~g} / \mathrm{m}$.

\section{REFERENCES}

VAn BOSSE, A.W. 1928. Liste des algues du Siboga, Rhodophycese, Gigartinales et Rhodymeniales. Siboga Expedite LIX $d$ : 408 - 424. CORDERO, P. A. Jr. 1977. Studies on Philippines marine red algae. Spec. Publ. Seto Mar. Biol.Lab. Serie IV: 258 pp.

DOTY, MS. 1970. The red algal genus Eucheuma in the PhUlipines. Hawaii Set Bot. Pap. (18) : $1-358$.

ISMAIL. W. 1982. Budidaya Laut di Indonesia. In : "Kondisi Lingkungan Pesfsfr dan Laut di Indonesia".

K. ROMIMOHTARTO and S.THAYIB Eds). LON - LIPI, LML 38 : 212- 233.

LEVRING, T. ; HA HOPPE and OJ. SCHMIDT 1969. Marine algae; a survey of research andutilization. Cram de Gruytei \& Co, Hamburg. Vol 1:421 pp.

MUBARAK, H. 1974. Laporan survey Eucheuma di perairan Maluku dan Nusa Tenggara Timur, Juli - November 1974. Laporan Penelitian Perikanan Laut, Jakarta 1:1 - 29.

MUBARAK, H. 1978. Kemungkinan-kemungkinan budidaya rumput laut di Kep. Am. Simposium Modernisasi Perikanan Rakyat, Jakarta 27-30 Junil978 : 1 - 20.

SAhupala, J.; OJC Sumadiharga;D. SAPUlete; LF. Weno and SulistiJo 1977. Hasil penelitian rumput laut di Pulau Keifing dan Geser, Maluku Tengah, November — De-sember 1977. Proyek Penelitian Kultivasi Rumput Laut Pm. Da. Tk. I Maluku, Ambon: 1 - 27.

SOEGIARTO, A. and SULISTIJO 1981. Farming and utilization of seaweeds in Indonesia. Paper on the UNESCO - SEAFDEC Symposium on the culture and use of algae in Southeast Asia. Iloilo, Philippines 8 - 12 Dec. $1981: 1$ - 11.

Soegiarto, A.; SUlistiJO; W.S. AtMADJA and R MUBARAK 1978. Rumput tout (Aigae) .manfaat, potensidan usaha budidaya. LON — LIPI, Jakarta : 61 pp.

SOERYODINOTO 1970. Report on the exploratory survey of the Gulf Bone and adjacent waters. LPL, Jakarta : 1 - 27.

UNRI 1975. Jenis-jenis rumput laut yang terdapat di Kepulauan Riau, Kecamatan-kecamatan Bintan Utara dan Bintan Timur, Fakultas Perikanan Universitas Riau : 1 - 25. 